\title{
MITES FLUCTUATION POPULATION ON PEACH TREE (Prunus persica (L.) Batsch) AND IN ASSOCIATED PLANTS ${ }^{1}$
}

\author{
CARLA ROSANA EICHELBERGER ${ }^{2}$, LIANA JOHANN ${ }^{3}$, \\ FERNANDA MAJOLO ${ }^{3}$, NOELI JUAREZ FERLA ${ }^{3}$
}

\begin{abstract}
Despite the importance of peach (Prunus persica (L.) Batsch) in Rio Grande do Sul, little is known about mites fluctuation population considered important to this crop. The objective of this study was to know the population diversity and fluctuation of mite species associated with Premier and Eldorado varieties in Roca Sales and Venâncio Aires counties, Rio Grande do Sul. The study was conducted from July 2008 to June 2009 when 15 plants were randomly chosen in each area. The plants were divided in quadrants and from each one a branch was chosen from which three leaves were removed: one collected in the apical region, another in the medium and the other in the basal region, totalizing 180 leaves/area. Five of the most abundant associated plants were collected monthly in enough amounts for the screening under the stereoscopic microscope during an hour. A total of 1,124 mites were found belonging to 14 families and 28 species. Tetranychus ludeni Zacher, 1913, Panonychus ulmi (Koch, 1836) and Mononychellus planki (McGregor, 1950) were the most abundant phytophagous mites, whereas Typhlodromalus aripo Deleon, 1967 and Phytoseiulus macropilis (Banks, 1904) the most common predatory mites. The period of one hour under stereoscopic microscope was enough to get a representative sample. In both places evaluated the ecologic indices were low, but little higherin Premier (H' 0.56; EqJ: 0.43) when compared to Eldorado (H' 0.53; EqJ 0.40). In Premier constant species were not observed and accessory only Brevipalpus phoenicis (Geijskes, 1939), T. ludeni and T. aripo. Higher abundance was observed in December and January and bigger amount in April. Already in Eldorado, T. ludeni and P. ulmi were constants. Greater abundance was observed in November and December, whereas grater richness in December and January. In both orchards were not found mites in buds. Tetranychus ludeni is the most abundant phytophagous mites with outbreak population in November, December and January and high predator diversity was observed on associated plants and on peach plants, indicating the existence of species mobility in peach orchard.
\end{abstract}

Index terms: Acari, biological control, Panonychus ulmi, Tetranychus ludeni, Typhlodromalus aripo.

\section{FLUTUAÇ̃̃O POPULACIONAL DE ÁCAROS NA CULTURA DO PESSEGUEIRO (Prunus persica (L.) Batsch) E EM PLANTAS ASSOCIADAS}

RESUMO - Apesar da grande importância da cultura do pêssego [Prunus persica (L.) Batsch] no Rio Grande do Sul, pouco se conhece sobre a diversidade e a flutuação populacional de ácaros considerados importantes para esta cultura. O objetivo deste trabalho foi conhecer a flutuação populacional das espécies acarinas associadas às cultivares Premier e Eldorado nos municípios de Roca Sales e Venâncio Aires, Rio Grande do Sul. O estudo foi realizado no período de julho de 2008 a junho de 2009, quando foram amostradas 15 plantas escolhidas ao acaso numa área em cada município. As plantas foram divididas em quadrantes, e de cada quadrante foi escolhido um galho de onde foram retiradas três folhas das regiões apical, mediana e basal, totalizando 180 folhas/área. Foram coletadas, mensalmente, parte de cinco plantas não cultivadas mais abundantes. O período de uma hora sob microscópio estereoscópio foi suficiente para se obter uma amostra representativa. Um total de 1.124 ácaros foi coletado pertencentes a 14 famílias e 28 espécies. Tetranychus ludeni Zacher, 1913, Panonychus ulmi (Koch, 1836) e Mononychellus planki (McGregor, 1950) foram os ácaros fitófagos mais abundantes, enquanto Typhlodromalus aripo Deleon, 1967 e Phytoseiulus macropilis (Banks, 1904) os ácaros predadores mais comuns. O esforço amostral foi suficiente. Nos dois pomares avaliados, os índices ecológicos foram baixos, mas um pouco superiores em Premier (H’0,56; EqJ: 0,43) quando comparados a Eldorado (H' 0,53; EqJ 0,40). Em Premier não foram observadas espécies constantes, apenas acessórias com Brevipalpus phoenicis (Geijskes, 1939), T. ludeni e T. aripo. Maior abundância foi observada em dezembro e janeiro, e maior quantidade em abril. Em Eldorado, T. ludeni e P. ulmi foram constantes. Maior abundância foi observada em novembro e dezembro, e maior quantidade em dezembro e janeiro. Não foram observados ácaros nas gemas. Tetranychus ludeni é o ácaro fitófago mais comum, com picos populacionais em novembro, dezembro e janeiro. Alta diversidade de ácaros predadores foi observada tanto em plantas associadas como em plantas de pessegueiro, indicando mobilidade das espécies predadoras na cultura.

Termos para indexação: Acari, controle biológico, Panonychus ulmi, Tetranychus ludeni, Typhlodromalus aripo.

'(Trabalho 189-10). Recebido em: 16-08-2010. Aceito para publicação em: 24-05-2011. Part of the dissertation presented in Environment and Development pos graduate program, UNIVATES University Center, Mailbox 155, CEP 95900-000 Lajeado-RS, Brazil. ${ }^{2}$ Mester in Environment and Developing, UNIVATES University Center, Mailbox 155, CEP 95900-000 Lajeado-RS, Brazil. E-mail: carla-rosana@bol.com.br.

${ }^{3}$ Laboratory of Acarology, Museum of Natural Science, UNIVATES University Center, Mailbox 155, CEP 95900-000 Lajeado-RS, Brazil.E-mails: lianajohann@yahoo.com.br; fernandamajolo@hotmail.com;njferla@univates.br. 


\section{INTRODUCTION}

The peach culture represents an important activity to fruit culture sector to the state of Rio Grande do Sul. In Roca Sales and Venâncio Aires counties, fruit cultivation represents income and stimulus to farming family. According to IBGE (2007), Roca Sales produced 520 tones while Venâncio Aires 72 tones of fruit.

The peach culture is attacked by diseases and pests where mites stand up. In Prunus spp., the Eriophyoidea Aculops berochensis Keifer and Delley 1971, Aculus fockeui (NALEPA; TROUESSART, 1891), Diptacus gigantorhyncus (NALEPA,1892) and Eriophyes insidiosus (KEIFER; WILSON 1955) are reported as economic level (CASTAGNOLI; OLDFIELD, 1996). Aculus fockeui is widely recognized as causing symptoms on young leaves of its hosts which appear similar to those caused by infections by viruses. Their feeding produces the well-known silvering of peach foliage that develops late in the season just before the leaves drop. Another result of mite's feeding has been termed "yellow spot", which is characterized by yellow spotting and chlorosis alongside the veins, accompanied by upward longitudinal folding to the leaf margin into a trough like structure (CASTAGNOLI; OLDFIELD, 1996; KEIFER et al., 1982; JEPPSON et al., 1975). In severe infestations reduce the production and quality of fruits (KEIFER et al., 1982; JEPPSON et al., 1975). In United State of America, Metaseiulus occidentalis (Nesbitt 1951) and Zetzellia mali (Ewing 1917) are important mite predator of this species; in Italy, Agistemus collyerae Gonzales, 1963, Amblyseius andersoni (Chant 1957) and Amblyseius stipulatus Athias-Henriot 1960 were found associated with high population of eriophyds mite in this crop (CASTAGNOLI;OLDFIELD, 1996).

Among the tetranychids mites stand up Tetranychus urticae (KOCH, 1836), Tetranychus desertorum (Banks, 1905) and Tetranycus mexicanus (McGREGOR, 1950) (FLECHTMANN, 1979). The active phases of these mites develop on abaxial face of leave beginning along the main vein and expanding around the limb as the population grows. They weave a large amount of web. On the underside of the leave, nearby at the veins, notice white and silvery gray patches and in the upper face appears chlorotic patches. Intensity attached leaves show the limb slowly wavy and the young leaves reaching to bend over and wrapping due to attack (FLECHTMANN, 1979; JEPPSON et al., 1975). Phytoseiidae mites are natural enemies more commonly associated to tetranychids in natural environment and agroecossystems (McMURTRY; CROFT, 1997).

Although the peach culture has an economic importance to the state, little is known about the population dynamic, as well as the species associated to culture. This fact highlights the importance to realize dynamics studies, because only with information would be possible to suggest strategies on the management of pest mite. This work aims to know the diversity and population fluctuation of mites associated to Premier and Eldorado cultivars and plants associated, on harvest 2008/2009, in state of Rio Grande do Sul.

\section{MATERIALS AND METHODS}

This study was conducted monthly from July 2008 to June 2009 in the peach culture in two orchards in the counties of Roca Sales $\left(29^{\circ} 11^{\prime} \mathrm{S} 51^{\circ}\right.$ $47^{\prime}$ O), with the cultivar Premier, and in Venâncio Ai-

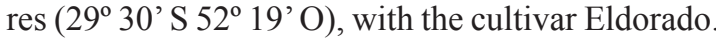
Both areas had three hectares and ten years old. No pesticides treatment was applied in the areas during the study. Premier area was localized nearby tobacco crop, while in Eldorado area also was cultivated other fruits as guava, orange and bergamot.

Monthly were randomly sampled 15 plants, which were divided into quadrants and from each one were chosen a branch where were removed three leaves, one in the apical region, one in the medium and another in the basal, totalizing 180 leaves/area. At the same time, parts of five associated plants more commons were collected from every area for an hour sampling effort under microscope stereoscopic to count, collect and remove the mites. The counting was made directly on the leaves with microscopic stereoscopic observing both leaves faces. Mites where collected with fine paintbrush and stored in alcohol $70 \%$ to posterior mounting and identification. All mites were mounting at Hoyer's medium (JEPPSON et al., 1975). Representative specimens of each species found were deposited on the mites reference collection of the Museum of Natural Science at UNIVATES University Center (ZAUMCN), Lajeado, Rio Grande do Sul.

The J-Shanon evenness indicated the preference between the sampled areas (ZAR, 1999). To analyze the evenness and Shannon-Wiener index was utilized the software Diversity of Species - DivEs 2.0 version. The species dominance was defined using the formula: $\mathrm{D} \%=(\mathrm{i} / \mathrm{t}) .100$, where $\mathrm{i}=$ total specimens and $\mathrm{t}=$ total of specimens collected and clustered according to the categories establish by Friebe (1983); 
eudominant ( $\left.{ }^{3} 10 \%\right)$, dominant $(5 £ 10 \%)$, subdominant $(2 £ 5 \%)$, eventual $(1 £ 2 \%)$ and rare $(\mathrm{D}<1 \%)$. Climate Parameters was provided by UNIVATES University Center Meteorological Station (2009).

\section{RESULTS}

From a total of 1,124 mites, 28 species were collected belonging to 14 families (Table 1). Phytoseiidae was the family with higher diversity, with nine species, followed by Tetranychidae, with three species. Tetranychus ludeni Zacher, 1913, Panonychus ulmi (KOCH, 1836) and Mononychellus planki (McGREGOR, 1950) were the most abundant phytophagous mites, whereas Typhlodromalus aripo Deleon, 1967 and Phytoseiulus macropilis (BANKS, 1904) the most common predatory mites. The sample size was enough, because the collector curve found the stability in May, after eleven collects (Figure 1). Thus, the number would be the minimum samples required to represent satisfactorily the mite community in peach crop, in Taquari Valley. However, the number of samples was sufficient when also were evaluated the associated plants. Throughout the period, Venâncio Aires orchard showed most species. In both places evaluated the ecologic indices were low, but a few superior in Premier (H' 0.56; EqJ: 0.43) when compared to Eldorado (H' 0.53; EqJ 0.40). Tetranychus ludeni was eudominant in both cultivars and P. ulmi and $A$. fockeui were dominant only in Venâncio Aires.

In Roca Sales, constant species was not observed and accessory only Brevipalpus phoenicis (GEIJSKES, 1939), T. ludeni and T. aripo. All other species (17 species) were accidentals (Table 1). Greater abundance was observed in December and January and bigger amount in April, with 10 species and December and March, with nine species. Whereas, in Venâncio Aires, T. ludeni and P. ulmi were constants and A. fockeui, Oribatida and Tydeus sp. accessories. Sixteen species were accidentals. Greater abundance was observed in November and December whereas grater richness in December and January with 12 and 13 species, respectively. In both orchards weren't found mites in buds.

Prunus persica showed bigger amount with 14 species, followed by Lantana camara L. with ten species and Synedrella nodiflora Gaertn. with eight species. In both cultivars, fifteen associated plants did not show mites (Table 2).

In both areas, largest population of T. ludeni were observed in November and December as much on peach leaves as on plants associated. In Venâncio Aires were 635 specimens and in Roca Sales, only
192 specimens. Typhlodromalus aripo, present only in associated plants was more abundant in Venâncio Aires (14) than in Roca Sales (8). Phytoseilus macropilis was the most common predator on peach plants, mainly in Venâncio Aires. The main species did not show preference among apical, median and basal peach leaves. The frequency of $T$. ludeni, in Roca Sales, was higher on associated plants among January, March and April. Differently, in Venâncio Aires, was higher on peach plants from October to May.

The population fluctuation was different in counties evaluated. In Roca Sales, T. ludeni stand up higher population in December and January, with population pick in January when achieved 0.65 mite/leaf (Figure 2A). In this time phytoseiids population were high and kept this level till April. In December and January the predator species was linked to T. ludeni. However, between February and April other food resources were utilized, because $T$. ludeni was absent. The high population period of T. ludeni was preceded by low precipitations and relative humidity (Figure $2 \mathrm{C}$ ). These factors plus the leaves peach ripening may have influenced the rising of this herbivorous mite.

Tetranychus ludeni, in Venâncio Aires, had the population pick in December with two mites/leaf as P. ulmi was present from November to May, with population outbreak on November and April (Figure 2B). In December when increased the phytoseiid population, decreased the population of tetranychids mites. All the same predator species were observed from August to January lacking tetranychids in this time.

\section{DISCUSSION}

The mite fauna associated to peach culture and the ecologic indices were similar in both environments. However, the frequency and ecologic niche of mites were different in the evaluated areas because the mite fauna showed difference between the areas and this difference occurred probably by farmers distinct management. In Venâncio Aires property the peach orchards is localized nearby tobacco crop and its management may caused negative impact over predator mites benefiting the herbivorous population mite. Besides, it is important to consider that the high mite populations can be linked to climate factors, because the high populations in both counties were preceded for a time with low precipitation and relative humidity.

Tetranychus ludeni was the keystone species because used as resource others species in both environments. It was more frequently with outbreak 
population in December in both counties available. This species and P. ulmi did not show preference by extract plant differently observed by Moraes and Flechtmann (2008) in cotton crop, where $T$. ludeni preferred apical and median leaves of the plant. In Europe, P. ulmi is considered an economic importance to apple culture and their attacks are particularly dangerous in the begging of the spring and at the end of the summer. In spring, can cause leaves fall, harming flowers and bud development, while in the end of the summer, high population can bring leaves bronzing and affect the quality of fruit (SCHRUFT, 1985). According to Ferla and Botton (2008), in grapevine, P. ulmi cause bronzing with red patches on adaxial face of leaves. Differently, Mononychellus planki it's present only in associated plants, already has been found in soybean in the state of Rio Grande do Sul (GUEDES et al., 2004; ROGGIA et al., 2008), where their populations seem be increasing in recent years (MORAES et al., 2006).

Iolinidae and Phytoseiidae was the most common predator mites associated to herbivorous mite's population on peach plants and associated plants. Typhlodromalus aripo, the most common predator, was also more common on associated plants to strawberry crop in state of Rio Grande do Sul (FERLA et al., 2007) and commonly associated to Mononychellus tananjoa (Bondar 1938) in cassava culture in northeast of Brazil (MORAES et al., 1990). Also is reported in others cultures and associated plants (MORAES; McMURTRY, 1983; MORAES et al., 1990; NORONHA et al., 1997).

High predator diversity was observed on associated plants and many also on peach plants, indicating the existence of species mobility in environment as reported by Altieri et al., (2003). The environmental heterogeneity increasing in monoculture system can be an alternative to pest management, because change the microclimate, provides trap plants, physic fence to herbivorous and reservoir of predators, can decrease the species-pest dominance (DAUD; FERES, 2005). Studies show that the environmental heterogeneity is a benefit factor to control the abundance of dominant phythophagous (ALTIERI et al., 2003). With that, it is suggested that the associated plants be kept in peach orchards, once was observed great diversity of predator species and they can migrate to peach plants when in herbivorous mites presence.

\section{Collector curve}

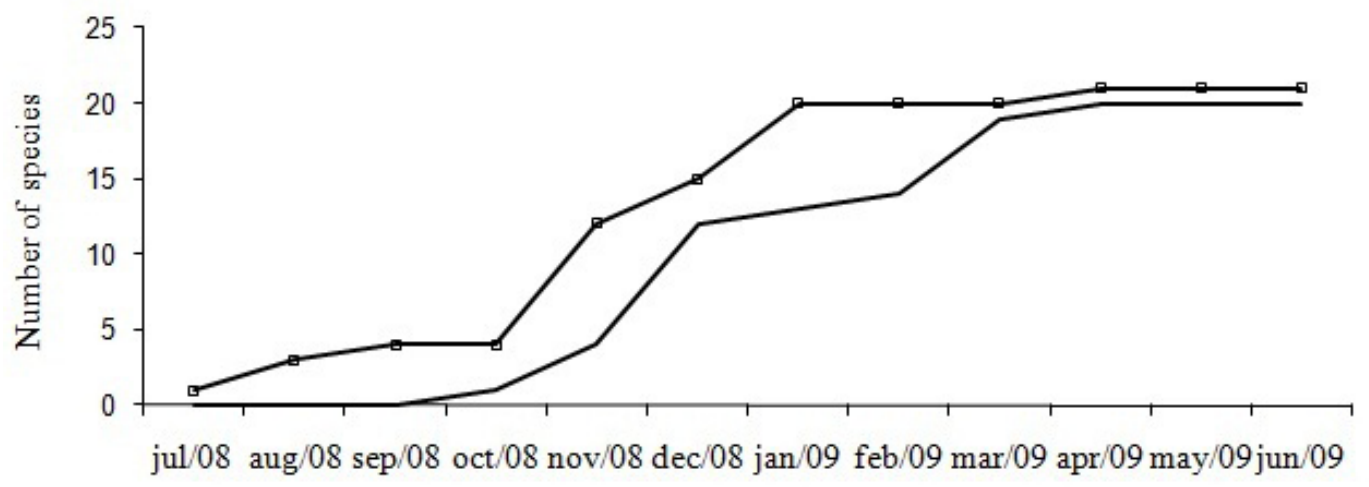

Months

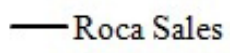

$\rightarrow$ Venâncio Aires

FIGURE 1 - Collector curve showing the sampling effort realized from July 2008 to June 2009, in Roca Sales and Venâncio Aires counties. 
TABLE 1- Abundance of predator and phytophagous mites collected on peach leaves and plant associated. Period July 2008 to June 2009, in Roca Sales and Venancio Aires countries, Brazil.

\begin{tabular}{|c|c|c|c|c|c|c|c|}
\hline \multirow{3}{*}{ Family } & \multirow{3}{*}{ Morpho-species or species } & \multicolumn{3}{|c|}{ Venâncio Aires } & \multicolumn{3}{|c|}{ Roca Sales } \\
\hline & & \multicolumn{3}{|c|}{ Eldorado } & \multicolumn{3}{|c|}{ Premier } \\
\hline & & Total & Freq. $(\%)$ & Dominance & Total & Freq. $(\%)$ & Dominance \\
\hline Acaridae & Caloglyphus sp. & & & & 13 & 4.94 & Subdominant \\
\hline Cheyletidae & $\begin{array}{c}\text { Cheletomimus } \\
\text { (Hemicheyletia) wellsi }\end{array}$ & & & & 1 & 0.38 & Rare \\
\hline \multirow[t]{2}{*}{ Cunaxidae } & Armascirus sp. & & & & 2 & 0.76 & Rare \\
\hline & Cunaxoides sp. & & & & 1 & 0.38 & Rare \\
\hline Eriophydae & Aculus fockuei & 45 & 5.22 & Dominant & & & \\
\hline \multirow[t]{2}{*}{ Iolinidae } & Pronematus anconai & 3 & 0.34 & Rare & 1 & 0.38 & Rare \\
\hline & Pronematus sp. & 2 & 0.23 & Rare & 1 & 0.38 & Rare \\
\hline Oribatida & Oribatida & 14 & 1.62 & Eventual & & & \\
\hline \multirow[t]{8}{*}{ Phytoseiidae } & Typhlodromips mangleae & & & & 9 & 3.42 & Subdominant \\
\hline & Amblydromalus manihoti & & & & 2 & 0.76 & Rare \\
\hline & Euseius concordis & & & & 5 & 1.9 & Eventual \\
\hline & Euseius ho & 3 & 0.34 & Rare & 1 & 0.38 & Rare \\
\hline & Neoseiulus californicus & 1 & 0.11 & Rare & & & \\
\hline & Phytoseiulus macropilis & 7 & 0.81 & Rare & 3 & 1.14 & Eventual \\
\hline & Proprioseiopsis dominigos & 2 & 0.23 & Rare & 5 & 1.9 & Eventual \\
\hline & Typhlodromalus aripo & 14 & 1.62 & Eventual & 8 & 3.04 & Subdominant \\
\hline Pyemotidae & Pygmephorus sp. & 1 & 0.11 & Rare & & & \\
\hline \multirow[t]{2}{*}{ Stigmaeidae } & Agistemus braziliensis & 1 & 0.11 & Rare & & & \\
\hline & Agistemus floridanus & 5 & 0.58 & Rare & 2 & 0.76 & Rare \\
\hline \multirow[t]{3}{*}{ Tarsonemidae } & Fungitarsonemus sp. & 19 & 2.2 & Subdominant & 3 & 1.14 & Eventual \\
\hline & Fungitarsonemus sp.1 & 8 & 0.92 & Rare & & & \\
\hline & Tarsonemus sp. & 1 & 0.11 & Rare & 3 & 1.14 & Eventual \\
\hline Tenuipalpidae & Brevipalpus phoenicis & & & & 4 & 1.52 & Eventual \\
\hline \multirow[t]{3}{*}{ Tetranychidae } & Mononychellus planki & 24 & 2.78 & Subdominant & & & \\
\hline & Panonychus ulmi & 44 & 5.11 & Dominant & & & \\
\hline & Tetranychus ludeni & 635 & 73.75 & Eudominant & 192 & 73 & Eudominant \\
\hline \multirow[t]{2}{*}{ Tydeidae } & Lorryia formosa & 14 & 1.62 & Eventual & & & \\
\hline & Tydeus sp. & 12 & 1.39 & Eventual & 5 & 1.9 & Eventual \\
\hline \multirow[t]{3}{*}{ Winterschmidtiidae } & Czenpinskia sp. & 6 & 0.69 & Rare & 2 & 0.76 & Rare \\
\hline & Abundance & 861 & & & 263 & & \\
\hline & Richness & 21 & & & 20 & & \\
\hline
\end{tabular}


TABLE 2 - Mites collected on associated plants and on peach leaves in Rio Grande do Sul. Period July 2008 to June 2009, in Roca Sales (Premier) and Venâncio Aires (Eldorado) counties.

\begin{tabular}{|c|c|c|c|c|}
\hline Family & Plants species & Associated mites & $\begin{array}{c}\boldsymbol{V A} \\
\boldsymbol{E}\end{array}$ & $\begin{array}{c}R S \\
P\end{array}$ \\
\hline \multirow[t]{16}{*}{ Asteraceae } & Artemisia $\mathrm{sp}$. & - & - & - \\
\hline & Galinsoga parviflora & - & - & - \\
\hline & Sonchus oleraceus & - & - & - \\
\hline & Erechites valerianaefolia & - & - & - \\
\hline & Blainvillea biaristata & - & - & - \\
\hline & Ageratum conyzoides & - & - & - \\
\hline & Sonchus sp. & - & - & - \\
\hline & Pterocaulon lanatum & - & - & - \\
\hline & \multirow[t]{4}{*}{ Pterocaulon virgatum } & Amblydromalus manihoti & - & 1 \\
\hline & & Euseius concordis & - & 1 \\
\hline & & Tetranychus ludeni & - & 3 \\
\hline & & $\begin{array}{l}\text { Cheletomimus (Hemicheyletia) } \\
\text { wellsi }\end{array}$ & - & 1 \\
\hline & \multirow[t]{3}{*}{ Hypochoeris sp. } & Oribatida & 4 & - \\
\hline & & Proprioseiopsis dominigos & 1 & - \\
\hline & & Typhlodromalus aripo & 6 & - \\
\hline & Hypochoeris radicata & - & - & - \\
\hline \multirow[t]{25}{*}{ Compositae } & Ambrosia tenuifolia & Typhlodromalus aripo & 6 & - \\
\hline & \multirow[t]{2}{*}{ Taraxacum officinale } & Oribatida & 2 & - \\
\hline & & Tydeus sp. & 11 & - \\
\hline & Senecio sp. & Oribatida & 1 & - \\
\hline & Conyza canadensis & Tetranychus ludeni & 20 & - \\
\hline & \multirow[t]{3}{*}{ Solidago chilensis } & Oribatida & 1 & - \\
\hline & & Phytoseiulus macropilis & 2 & - \\
\hline & & Tetranychus ludeni & 7 & - \\
\hline & \multirow[t]{2}{*}{ Synedrellopsis grisebachii } & Oribatida & 1 & - \\
\hline & & Tetranychus ludeni & 1 & - \\
\hline & \multirow[t]{7}{*}{ Bidens pilosa } & Brevipalpus phoenicis & - & 2 \\
\hline & & Czenpinskia sp. & 2 & - \\
\hline & & Neoseiulus californicus & 1 & - \\
\hline & & Phytoseiulus macropilis & - & 1 \\
\hline & & Pronematus anconai & 1 & - \\
\hline & & Tetranychus ludeni & 2 & 47 \\
\hline & & Typhlodromalus aripo & - & 2 \\
\hline & \multirow[t]{8}{*}{ Synedrella nodiflora } & Agistemus floridanus & 2 & - \\
\hline & & Amblydromalus manihoti & - & 1 \\
\hline & & Czenpinskia sp. & 1 & - \\
\hline & & Oribatida & 5 & - \\
\hline & & Proprioseiopsis dominigos & 1 & - \\
\hline & & Tetranychus ludeni & - & 43 \\
\hline & & Typhlodromalus aripo & - & 3 \\
\hline & & Tarsonemus sp. & - & 1 \\
\hline \multirow[t]{3}{*}{ Cucurbitaceae } & \multirow[t]{3}{*}{ Cayaponia podantha } & Aculus fockeui & 1 & - \\
\hline & & Czenpinskia sp. & 1 & - \\
\hline & & Tarsonemus sp. & 1 & - \\
\hline \multirow[t]{4}{*}{ Convolvulceae } & \multirow{2}{*}{ Ipomoea nil } & Phytoseiulus macropilis & - & 1 \\
\hline & & Tetranychus ludeni & - & 36 \\
\hline & \multirow{2}{*}{ Ipomoea sp. } & Proprioseiopsis dominigos & - & 2 \\
\hline & & Typhlodromalus aripo & - & 1 \\
\hline Labiatae & Leonurus sibiricus & Brevipalpus phoenicis & - & $\begin{array}{c}1 \\
\text { uacão }\end{array}$ \\
\hline
\end{tabular}


continua

\begin{tabular}{|c|c|c|c|c|}
\hline \multirow[t]{2}{*}{ Loganiaceae } & Buddleja brasiliensis & Agistemus floridanus & - & 1 \\
\hline & & Cunaxoides sp. & - & 1 \\
\hline \multirow[t]{9}{*}{ Malvaceae } & Sida santaremnensis & Brevipalpus phoenicis & - & 1 \\
\hline & & Caloglyphus sp. & - & 1 \\
\hline & & Mononychellus planki & 4 & - \\
\hline & & Pygmephorus sp. & 1 & - \\
\hline & & Tetranychus ludeni & 9 & - \\
\hline & & Tydeus sp. & - & 1 \\
\hline & Sida urens & - & - & - \\
\hline & Sida rhombifolia & - & - & - \\
\hline & Sida spinosa & Mononychellus planki & 20 & - \\
\hline Oxalidaceae & Oxalis corniculata & - & - & - \\
\hline \multirow[t]{2}{*}{ Poaceae } & Paspalum dilatatum & - & - & - \\
\hline & Brachiaria brizantha & - & - & - \\
\hline \multirow[t]{14}{*}{ Rosaceae } & Prunus persica & Aculus fockeui & 44 & - \\
\hline & & Agistemus brasiliensis & 1 & - \\
\hline & & Agistemus floridanus & 3 & 1 \\
\hline & & Caloglyphus sp. & - & 12 \\
\hline & & Euseius ho & 3 & 1 \\
\hline & & Fungitarsonemus sp. & 19 & 3 \\
\hline & & Fungitarsonemus sp.1 & 8 & \\
\hline & & Lorrya formosa & 14 & - \\
\hline & & Panonychus ulmi & 44 & - \\
\hline & & Phytoseiulus macropilis & 3 & 7 \\
\hline & & Pronematus anconai & - & 1 \\
\hline & & Tarsonemus sp. & - & 2 \\
\hline & & Tetranychus ludeni & 594 & 57 \\
\hline & & Tydeus sp. & 1 & 4 \\
\hline Sapindaceae & Cardiospermum halicacabum & - & - & - \\
\hline Thelypteridaceae & Thelypteris dentata & - & - & - \\
\hline \multirow[t]{11}{*}{ Verbenaceae } & Lantana camara & Armascirus sp. & - & 2 \\
\hline & & Cunaxoides sp. & - & 1 \\
\hline & & Czenpinskia sp. & 2 & 2 \\
\hline & & Euseius concordis & - & 4 \\
\hline & & Phytoseiulus macropilis & 2 & - \\
\hline & & Pronematus anconai & 3 & 1 \\
\hline & & Proprioseiopsis dominigos & - & 3 \\
\hline & & Tetranychus ludeni & 2 & 6 \\
\hline & & Typhlodromalus aripo & - & 2 \\
\hline & & Typhlodromips mangleae & - & 9 \\
\hline & & Total & 861 & 263 \\
\hline
\end{tabular}




\section{Premier - Roca Sales - RS}

A

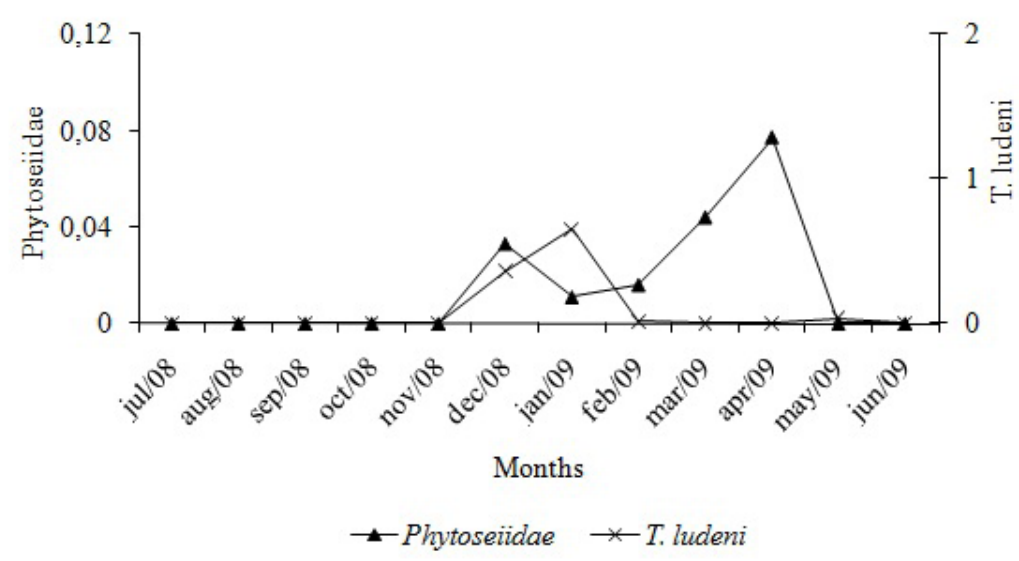

Eldorado - Venâncio Aires - RS

B

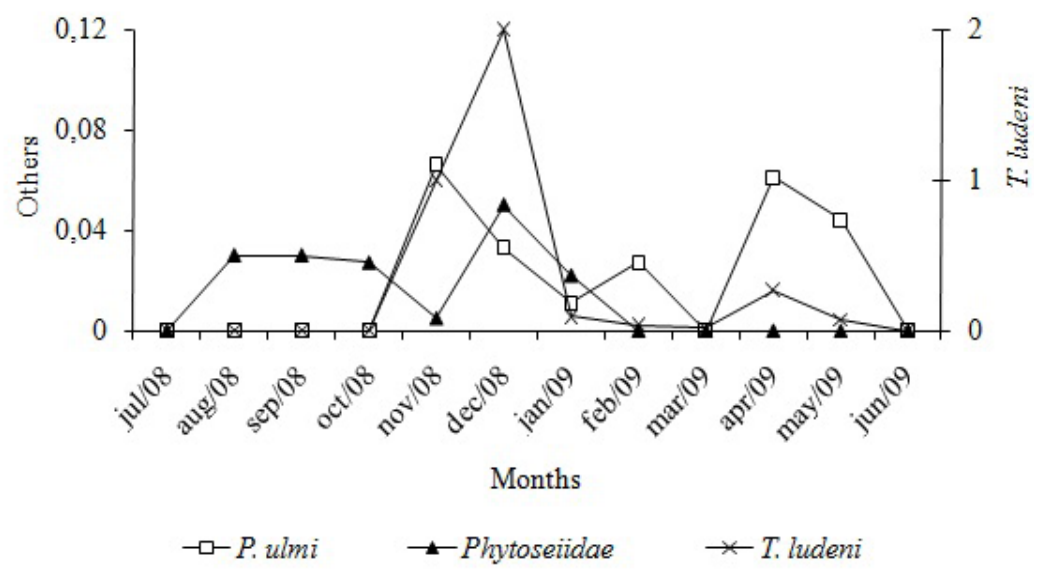

FIGURE 2 - A-B Mite's fluctuation population on peach orchards, in Roca Sales (Premier) and Venâncio Aires (Eldorado) counties; C - Climate Parameters of UNIVATES University Center Meteorological Station, Lajeado, from July 2008 to June 2009, state of Rio Grande do Sul, Brazil.

\section{CONCLUSIONS}

1-Tetranychus ludeni, Panonychus ulmi and Mononychellus planki were the phytophagous mites more abundant. Typhlodromalus aripo and Phytoseiulus macropilis are the most common predator mites.

2-Tetranychus ludeni is the most important phythophagous mites in peach culture in Taquari Valley (Roca Sales and Venâncio Aires - RS) with outbreak population in November, December and January.
3-High predator diversity was observed on associated plants and on peach plants, indicating the existence of species mobility in peach orchard.

\section{ACKNOWLEDGMENTS}

Thanks to UNIVATES, University Center for the financial support of the project and the anonymous referees for suggestions and comments to the manuscript. 


\section{REFERENCES}

ALTIERI, M. A.; SILVA, E. M.; NICHOLLS, C. I. $O$ papel da biodiversidade no manejo de pragas. Ribeirão Preto: Editora Holos, 2003, 226p.

CASTAGNOLI, M.; OLDFIELD, G. N. Other Fruit Trees and Nut Trees. In: E. E. LINDQUIST, E.E.; SABELIS, M.W.; BRUIN. J. (Ed.). Eriophyoid mites: their biology, natural enemies and control. Amsterdam: Elsevier, 1996. p. 543-559.

DAUD, R. D.; FERES, R. J. F. Diversidade e flutuação populacional de ácaros (Acari: Arachnida) em Mabea fistulifera Mart. (Euphorbiaceae). De dois fragmentos de Mata Estacional Semidecídua em São José do Rio Preto, São Paulo, Brasil. Neotropical Entomology, São José do Rio Preto, v.34, p. 191-201, 2005.

FERLA, N. J.; BOTTON, M. Ocorrência do ácaro vermelho europeu associado à cultura da videira no Rio Grande do Sul, Brasil. Ciência Rural, Santa Maria, v.38, n.6, p.1758-1761, 2008.

FERLA, N.J.; MARCHETTI, M.M.; GONÇALVES, D. Ácaros predadores (Acari) associados à cultura do morango (Fragaria sp., Rosaceae) e plantas próximas no Estado do Rio Grande do Sul. Biota Neotropica. Campinas, v.7, n. 2, p.1- 8, 2007.

FERLA, N.J.; MORAES, G. J. DE. Biologia de Agistemus floridanus Gonzalez (Acari: Stigmaeidae). Revista Brasileira de Zoologia, São Paulo, v.20. n.2, p. $261-264.2003$

FLECHTMANN, C.H.W. Ácaros de importância agrícola. São Paulo: Livraria Nobel, 1979. p. 108.

FRIEBE, B. Zur biologie eines buchenwaldbodens: 3. Die Kaferfauna. Carolinea, Karlshue, n. 41, p. 45-80, 1983.

GUEDES, J.V.C.; NAVIA, D.; FLECHTMANN, C.H.W.; LOFEGO, A.C. Ácaros fitófagos e predadores associados à soja no Rio Grande do Sul. In: CONGRESSO BRASILEIRO DE ENTOMOLOGIA, 20., 2004. Gramado. Programa e Resumos... p.170.

IBGE - Instituto Brasileiro de Geografia e Estatística. IBGE cidades Rio Grande do Sul: produção agrícola municipal. 2007. Disponível em: $<$ http://www. ibge.gov.br/cidadesat/topwindow.htm?1>. Acesso em: 10 jun. 2008.

JEPPSON, L. R.; KEIFER, H. H.; BAKER, E.W. Mites injurious to economic plants. Berkeley: University of California Press, 1975. 614p.
KEIFER, H.H.; BAKER, E.W.; KONO, T.; DELFINADO, M.; STYER, W.E. An illustrated guide to plant abnormalities caused by eriophyid mites in North America. Washington: United States Department of Agriculture, $1982.178 \mathrm{p}$.

MCMURTRY, J. A.; CROFT, B.A. Life-styles of phytoseiid mites and their roles in biological control. Annual Review of Entomology, Palo Alto, v.42, p. 291-321, 1997.

MORAES, G.J. DE; ALENCAR, J.A. DE; WENZEL NETO, F.; MERGULHÃO, S.M.R. Explorations for natural enemies of the cassava green mite in Brazil. In: SYMPOSIUM OF THE INTERNATIONAL SOCIETY OF TROPICAL ROOT CROPS, 8.,1988. Bangkok. Proceedings... p.351- 353.

MORAES, G.J. DE; FLECHTMANN, C.H.W. Manual de Acarologia: acarologia básica e ácaros de plantas cultivadas no Brasil. Ribeirão Preto: Holos, Editora, 2008. 308 p.

MORAES, G.J. DE; MCMURTRY, J. A. Phytoseiidae mites (Acarina) of northeastern Brazil, with descriptions of four new species. International Journal of Acarology, West Bloomfield, v.9, p.131148, 1983.

MORAES, G. J.; NAVIA, D.; GUEDES, J.V.C. Importância e manejo de ácaros em soja. In: REUNIÃO DE PESQUISA DE SOJA DA REGIÃO CENTRAL DO BRASIL,28., 2006, Uberaba. Ata... Londrina: Embrapa, 2006. v.1, p.77-89

NALEPA, A. Zur Kenntniss der Phyllocoptinin. Denkschriften der kaiserlichen Akademie der Wissenschaften. Mathematisch-naturwissenschaftliche Klasse, Wien, v.64, p.383-396, 1897

NORONHA, A. C. S.; CARVALHO, J.E.B.; CALDAS, R.C. Ácaros em citros nas condições de Tabuleiros Costeiros. Revista Brasileira de Fruticultura, Jaboticabal, v.19, n.3: p.373 - 376, 1997.

ROGGIA, S.; GUEDES, J. V. C.; KUSS, R. C. R.; ARNEMANN, J. A.; NÁVIA, D. Spider mites associated to soybean in Rio Grande do Sul, Brazil. Pesquisa Agropecuária Brasileira, Brasília, v. 43, n.3, p.295-301, 2008.

SCHRUFT, G.A. Grape. In: HELLE, W.; SABELIS, M.W. Spider mites: their biology, natural enemies and control. Amsterdan: Elsevier, 1985. p.359-366.

ZAR, J. H. Bioestatical analysis. 4. ed. New Jersey: Prentice-Hall, 1999. 663 p. 